\title{
COLLECTIVE DOMINANCE IN COMPETITION LAW AND POLICY OF THE EUROPEAN UNION: AN ASSESSMENT
}

\author{
Mia Mahmudur Rahim*
}

\begin{abstract}
The European Commission, supported by the European Courts, developed the framework for competition law and policy in Europe. One of the main purposes of this policy is to build a conceptual and legal foundation to promote market opening and to strengthen community institutions. In this policy framework, 'collective dominance' of firms in the European market is the utmost important issue. To deal with this issue, the competition law of the European Union is now relying more on the extensive network of national-level authorities and applying broadly consistent substantive rules. The notion of 'collective dominance' in European competition policy is in transition towards policy based on market-center economic considerations as regulations and guidelines increasingly follow an analytic format based on economic perspectives.
\end{abstract}

Ph.D candidate, Macquarie University, Australia. 


\section{INTRODUCTION}

One of the basic purposes of competition law of the European Union (EU) is to promote competition through the control of restrictive business practices but not to control any natural business activities of any commercial entity. Business competitions amongst firms ultimately enhance the overall efficiency of the business economy. This enhancement basically happens in two ways, namely:

- $\quad$ by encouraging price competition; and

- $\quad$ by forcing firms to produce more efficiently so as to compete on price with their rivals. ${ }^{1}$

These two ways can be frustrated by any or joint efforts of firms. To maximise the profit margin, firms can tilt the usual competitive edges of other firms and distort the market's usual environment. Thus, curbing abuses by firms that dominate markets and suppress competitors or harm consumers is one of the main subjects of EU competition policy. To deal with this issue, the competition law of the EU is now relying more on the extensive network of national-level authorities and applying broadly consistent substantive rules. The notion of 'collective dominance' in European competition policy is in transition towards a policy based on market-centered economic considerations as regulations and guidelines increasingly follow an analytic format based on economic perspectives.

This article starts with the assessment of the notion of 'collective dominance' in EU competition policy. Thereafter, it critically analyses the regulatory framework of EU competition policy regarding the practice of 'collective dominance' in Europe along with the leading cases and decisions of the European Commission and European Court of Justice ('ECJ'). Finally, it assesses the EC framework for implementing 'collective dominance' in the EU.

$1 \quad$ Peter Muchlinski. Multi National Enterprises and the Law (Oxford: Blackwell, 1999), 385. 


\section{'COLLECTIVE DOMINANCE' IN EU COMPETITION POLICY}

\section{A. General Perception}

In general, when a small number of large firms in a market are able to co-ordinate their actions and maintain prices above the competitive level then those firms are collectively dominating that market. These firms can pursue commercial policy independently ignoring natural market conditions and can present themselves as a single entity on the market. The phrase 'one or more undertakings' in Article 82 of the European Commission (EC) Treaty ${ }^{2}$ has both narrow and wide meanings. Even only, two undertakings can create a collective dominance. ${ }^{3}$ Collective dominance is usually defined with reference to market share depending on the correct definition of the relevant market and at 'other factors indicating dominance.' ${ }^{4}$ Other factors that would lead to collective dominance would be 'superior technology and efficiency,' 'access to key inputs,' 'product differentiation,' 'profit,' 'conducts,' 'performance' etc.

'Collective dominance' is a legal concept with no direct equivalence in economic principals though it has strong similarities with the economic concept of 'market power.' But so long EC competition law deals in commercial activities of business firms and the welfare of consumers, principals of market economy is obvious in any discussion of competition law. In line with idea, the ECJ in the European Sugar Industry case ${ }^{5}$ emphasised technical economic analysis on existing and anticipated conduct of competitors.

In the DIP case, ${ }^{6}$ the ECJ held that the link following the same conducts amongst the undertakings ultimately proves the collective

\footnotetext{
2 Which states to the effect that firms in a dominant position may not abuse that position.

3 Commercial Solvents v Commission, 1973.

$4 \quad$ Jones. A and Sufrin B. EC Competition Law (Oxford: Oxford University Press, 2001), 269.

5 Joined Cases No. 40-48, 50, 54-56, 111, 113 \& 114/73 [Decision No. 73/ 109].

6 DIP SpA v. Commune Di Bassano Del Grappa [1995] ECR 1-3257.
} 
dominance by those undertakings on the market. Here, the links are 'structural' and it may be created by contracts, that is, 'economic' in nature. ${ }^{7}$ However, ECJ also holds that contractual or other links are not always essential to determine any 'collective dominance. ${ }^{8}$ While there is no agreed 'test' for collective dominance, in the Commission's view the following factors in a market are typically thought to facilitate the same conducts through co-ordination amongst undertakers:

$\begin{array}{ll}\text { - } & \text { High concentration levels } \\ \text { - } & \text { Stable and symmetric market shares } \\ \text { - } & \text { Similarity of cost structures } \\ \text { - } & \text { Stagnant demand } \\ \text { - } & \text { Inelastic demand } \\ \text { - } & \text { Homogeneous products } \\ & \text { Levels of technological change }\end{array}$

Because of the use of some important market activators, a collective dominant position can play an important role on a market mainly because:

- A collective dominant position will be able to determine supply because of its control over output.

- $\quad$ The collective dominant position may increase its profits by creating scarcity through lowering output, thereby forcing the customers to pay higher prices for a non-substitute commodity.

- A collective dominant position may also prevent the entry of other competitors into the market.

To raise a 'collective dominance' there are two distinct elements to collusion in the economic sense: one is, how firms come to an agreement; for example, how they decide the price they should charge. This is usually referred to as 'co-ordination.' The second element is how to ensure that no one has an incentive to deviate from that price. This is what economists describe as the credibility of the co-ordination. Enforcement against explicit collusion is generally aimed at the

\footnotetext{
$7 \quad$ French-West African Shipowners' Committees v. Commission [1992] O.J L134/1.

8 Compagnie Maritime Belege Transport SA v Commission,Case No. C-395/96 [2002] 4 CMLR 1076.
} 
coordinating mechanism - firms are punished for just 'tying.' In this aspect the EC Merger Regulation ${ }^{9}$ is based firmly on the credibility of sustaining collusive prices in future. ${ }^{10}$

As there are differences between the co-operations in natural business activities amongst business firms, it is very difficult to determine collusive undertakings. In fact, collusive undertakings create collective dominance gradually. In this respect there are three pre-conditions for the establishment of collective dominance:

- $\quad$ the market must be sufficiently transparent for all members of the oligopoly to be aware of the other members' conduct in order to be able to adopt the same policy.

- $\quad$ there must be a retaliation mechanism which serves as an incentive not to depart from the common policy, in order to ensure that the situation of tacit coordination is sustainable over time. Although there is no requirement for a specific retaliation mechanism involving a degree of severity, sufficient deterrents must exist.

- $\quad$ the policy must be able to withstand the foreseeable reaction of existing and future competitors and consumers.

Therefore, it is important to maintain the discipline among the firms with collective market power otherwise if any or few firms depart from the same behavioural standard then the tacit coordination will be lost. Here, loss of coordination means a sharp price war that would be harmful to everyone. For this reason, collective dominance always stands on a very strong base.

The notion 'collective dominance' though not mentioned directly in Article 82, basically deals with almost all legal implications of collective dominance in EC competition law. It would be worth mentioning that the related meaning of 'dominant' and 'abuse' mentioned in Article 82 of the

$9 \quad$ Council Regulation (EC) No. 139/2004 of 20 Jan. 2004. The EC Merger Regulation was intended to provide a "level playing field" in a "onestop shop" for the review of mergers with significant cross border effect, see Parisi, J., A Simple Guide to the EC Merger Regulation (updated to 28 November 2007) sourced from http://www.ftc.gov/bc/ international/dors/EcMergerRegSimpleGuide.pdf.

$10 \quad$ Gencor v. Commission Case No. T-102/96 [1999] 4 CMLR 971. 
EC competition law fully covers the absence of the words-'collective' and 'dominance' because these terms have the most practical implementation. The ECJ in United Brands v. Commission ${ }^{11}$ defines dominant position as:

“....a position of economic strength enjoyed by an undertaking which enables it to prevent effective competition being maintained on the relevant market by affording it the power to behave to an appreciable extent independently of its competitors, customers and ultimately of its consumers.”

\section{B. Regulatory Approach}

Article 81 and 82 of the EC Treaty deal with agreement between firms and abuse of dominant position respectively. Agreements between firms are prohibited under Article 81 of the Treaty if they have the effect of preventing, restricting or distorting competition within the EU. Thus, Article 81(1) prohibits 'all agreements between undertakings, decisions by associations of undertakings and concerted practices which may affect trade between member States and which have as their object or effect the prevention, restriction or distortion of competition within the common market.' Article 81(2) declares such agreements to be void. Article 81(3), however, provides for exemptions from the Article 81(1) prohibition.

EU policy on dominant firms is dealt with under Article 82 of the EC Treaty. This article focuses on abuse of a dominant position in one or more markets affecting trade within the common market. In line with policy in the UK, dominance is not held to be an infringement of Article 82 but rather any conduct which amounts to an abuse of a dominant position may be dealt with under this provision. In terms of the US policy this implies the EU uses a 'rule of reason' approach rather than a per se prohibition in this case. Article 82 states that 'any abuse by one or more undertakings of a dominant position within the common market or in a substantial part of it shall be prohibited as incompatible with the common

$11 \quad$ United Brands Co. and United Brands Continental BVv. Commission [1978] 1 CMLR 429. 
market in so far as it may affect trade between Member States.' This article provides a list form, though not exhaustive, of abuse of a dominant position as-

- $\quad$ directly or indirectly imposing unfair purchase or selling prices or other unfair trading conditions

- $\quad$ limiting production, markets or technical developments to the prejudice of consumers;

- $\quad$ applying dissimilar conditions to equivalent transactions with other trading parties, thereby placing them at a competitive disadvantage;

- making the conclusion of contracts subject to acceptance by the other parties of supplementary obligations which by their nature or according to commercial usage, have no connection with the subject of such contracts.

Thus, anticompetitive agreements are prohibited and void in EU competition policy and something close to a per se rule can be used against hard-core conduct, though economic benefits can lead to exemption from the prohibition. Though the list of anti-competitive agreement and behavior is provided by Article 82 of the EU Treaty, this article tries to cover the generic basis of possible anti-competitive activities of firms as anti-competitive practices in Europe are done mainly in three ways:

- $\quad$ Through agreements or concerted practices between otherwise independent competitors that serve to reduce competition between them;

- $\quad$ Acquisition of dominant position in a market mergers and acquisitions though it may be pro-competitive. ${ }^{12}$

- $\quad$ Enforcement against cartels would be strengthened further if sanctions applied to individuals as well as firms; if that is not feasible under Community law, the Commission could promote and support the imposition of individual sanctions under the national laws of Member States.

Another important issue regarding the determination of collective dominance is the extent of dominance in particular cases. In this regard 
the EC has adopted the view that a market share of $50 \%$ or more will normally be seen as evidence of dominance, although other factors such as the strength of existing competitors and potential entry will also be taken into account. In addition, the Commission has stated that dominance is more likely to be found in the market share range of $40 \%$ to $50 \%$ than below $40 \%$, although undertakings with market shares below $40 \%$ could be considered to be in a dominant position. However, undertakings with market shares of no more than $25 \%$ are not likely to enjoy a (single) dominant position on the market concerned. ${ }^{13}$

\section{Implementation Dimension}

Collective dominance in EC Treaty law is mainly dealt with in Article 82 and in the EC Merger Regulation though it is one of the most controversial and complex issues for its dealings under these two laws. ${ }^{14}$ However, in the long run, the Commission is entitled to control cases of joint or collective or oligopolistic dominance under both, Article 82 and the EC Merger Regulation. ${ }^{15}$ In EC Treaty law 'collective dominance' was mainly developed by 1998 particularly by the ECJ's judgments in Kali und salz ${ }^{16}$ and Compagnie Maritime Belege Transport SA v Commission cases, ${ }^{17}$ CFI's judgments in Gencor v. Commission ${ }^{18}$ and the Commission's decisions in Airtours / First Choice Case. ${ }^{19}$

Article 82 of the EC Treaty law actually does not deal with a firm that holds a dominant position; rather it applies upon the abuse of that position. The legal definition of 'abuse' states the harm of market structure and the maintenance and development of competitions. ${ }^{20}$

\footnotetext{
13 DG Competition, The Application of Article 82 of the Treaty to Exclusionary Abuse (Discussion Paper, December 2005), 11. Whish, R. Competition Law, 14 ${ }^{\text {th }}$ Edition (UK:Butterworths), 1993. France v the European Community Commission (1998) E.C.R. 1-1375. Kali und Salz AG and Kali-Chemie AG v Commission of the European Communities. Joined cases 19 and 20-74. European Court Reports 1975 Page 00499. Judgment of the Court of 14 May 1975.

17 Compagnie Maritime Belege Transport SA v Commission,Case No. C-395/96 [2002] 4 CMLR 1076.

18 Gencor v. Commission Case No. T-102/96 [1999] 4 CMLR 971.

19 Airtours plc v. Commission (Case T-342/99) [2002] 5 CMLR 7.

$20 \quad$ Hoffman-La Roche Case. Case no 85/76 [1979] ECR 461.
} 
However, Article 82 does not provide a complete list of activities, which might be termed abusive. In this respect, the Commission is also not so clear and exhaustive.(Kali und Salz $A G$ and Kali-Chemie AG v Commission of the European Communities. Joined cases 19 and 2074. European Court reports 1975 Page 00499. Judgment of the Court of 14 May 1975).

Explicit arrangements between firms and their outputs on the market are mainly dealt with by Article 81 of EC Treaty law. So Article 82 can deal with any economic link outside Article 81. But the use of Article 82 to current market situations sometimes raises problems ${ }^{21}$ mainly in identifying the situations where this Article can be used. There is always a doubt in differentiating independent relationship and purposeful alignment amongst firms in all oligopolistic markets.

The particular difficulty lays in distinguishing behaviour that is the natural result of such markets and behaviour resulting from actual co-ordination of competitive activity by the operators concerned. Article 81(1) deals with cases of actual collusion and Article 82 applies in the unilateral abuse of a position of dominance. However, where neither of these are present, the Commission has tried to extend the workings of the EC Merger Regulation to cover these situations. It was argued in France v. Commission ${ }^{22}$ that the EC Merger Regulation does not cover the notion of 'one or more undertakings' rather Article 82 applies to the conduct of more than one undertaking. ${ }^{23}$ So these two notions differ while considering collective dominance. However, it was held that mergers tends to create a collective dominant position that falls within the purview of the EC Merger Regulation and the principal objective of both the treaties is to secure the general structure of the Community system of control of concentrations. Nevertheless, collective dominance based on non-collusive behavior fell outside the scope of Article 82. ${ }^{24}$

In EU competition law, natural collective dominance is not unlawful so long as it infringes Article 82 through abusing its market

21 Bishop S and WalkerM. Economics of EC Competition Law: Concepts, Application and Measurement (London: Sweet and Maxwell, 1999), 189.

22 France v Commission. (Case T-565/08). (2009/C 55/68).

23 Jones A and Sufrin B. EC Competition Law. (Oxford: Oxford University Press, 2001), 229.

$24 \quad$ Hoffman-La Roche Case. Case No. 85/76 [1979] ECR 461. 
power. But if the degree of interdependence between the oligopolists is such that it can easily restrict the output that reduces competitions and if this so happens, then the Commission can interfere. Even concentration can be prohibited because of the chance in it to impede effective competition within the common market. ${ }^{25}$ Moreover, ECJ holds that 'structural links' amongst undertakings are not always necessary in order for a finding of collective dominance to be made. ${ }^{26}$ On the other hand, mere presence of a single policy between two firms may be evident of collective dominance. ${ }^{27}$ This in fact, depends upon the impact on the competitive behaviour of the market. However, in this regard each case turns on its particular fact. Examples, that will be discussed are the Trans Atlantic Conference Agreement (TACA), Wanadoo Interactive and Clearstream Banking's cases.

\section{TACA}

This case concerned a network of agreement and rules operated by the Trans Atlantic Conference Agreement (TACA), a group of shipping companies who provided container freight transport services between northern EU ports and the US. In this case, TACA was involved in setting prices both internally within the EU and on trade between the northern Europe and the US. Trans-atlantic shipping services, however, were exempted from Article 81(1) of the EC Treaty under a block exemption for maritime transport introduced in 1987. In its investigation, the Commission found that TACA was involved in a number of agreements which potentially infringed Article 81. These included, in particular, the fixing of prices for trans-atlantic shipping services and also transport services within the EU. Given the block exemption, however, it opted to use Article 82 rather than Article 81 of the Treaty.

\footnotetext{
25 Gencor v. Commission Case No. T-102/96[1999] 4 CMLR 971.

26 Societa Italiana Vetro SpA v. Commission [1992] ECR II-1403.

$27 \quad$ Irish Sugar plc v Commission of the European Communities, Case T228/97 [1999] ECR -II- 2969[2000] All ER(EC) 198.
} 
In its investigation, the Commission found that TACA members accounted for over sixty percent of trade in the trans-atlantic market and hence would satisfy the requirement for collective dominance. In addition, TACA restricted the ability of its members to enter into service contracts with shippers which might have led to closer ties between individual shippers and shipping companies and it also encouraged potential new competitors to join TACA rather than act as independent firms. The commission argued that these policies violated the Article 82 provisions and imposed fines, in total, of 273 million Euros.

The importance of this case was that the Commission was able to use the collective dominance provisions of Article 82 since its way was blocked under Article 81.

\section{Wanadoo}

This case concerned Wanadoo Interactive (a subsidiary of France Telecom) which was alleged to have engaged in predatory pricing in the retail market for ADSL-based internet access services in France. In its investigation, the Commission argued that Wanadoo had adopted a conscious policy of setting low prices in order to prevent entry from taking place and, therefore, increased its market share in this fast growing market. In particular, in the period from March to August 2001, Wanadoo had set its prices well bellow the average variable cost while from August 2001 to October 2002 it had its set its prices on a par with average variable cost but significantly below the average total cost. Evidence for predatory pricing was found in large losses that Wanadoo made in internet access services. In addition, Wanadoo had been able to increase its share of the market from 46\% in January 2001 to $72 \%$ in September 2002, and a significant competitor (Mangoosta) had been forced out of the market (in August 2001). The abuse ended in October 2002 when France Telecom (as the wholesale supplier of ADSL service) 
reduced its price by $30 \%$. Following this, Wanadoo stopped setting prices below average cost and this allowed other suppliers to provide more effective competition in the market. Wanadoo was fined 10.4 million Euros for its abuse of its dominant position. ${ }^{28}$

This case relates to the particular problem whereby dominant forms seek to prevent entry or restrict competition as new markets are developed in IT, and in other areas as well.

\section{Clearstream}

This concerned Clearstream Banking's refusal to supply cross border securities clearing and settlement services and the setting of discriminatory prices. The case involved a refusal by Clearstream (a subsidiary of Clearstream International) to supply clearing and settlement services to Euroclear Bank for registered securities issued under German law. Given that Clearstream was effectively the only depository of such securities, this restricted the operation of Euro clear cross boarder clearing and settlement service. The refusal of supply operated for a two year period up to November 2001. In addition, the Commission found the Clearstream had charged Euroclear higher prices for its services than it charged other securities depositories outside Germany in the period between January 1997 to January 2002, and that these differences did not reflect a difference in costs. The Commission found, on both counts, that Clearstream had abused its dominant position in the market for cross border clearing and settlement services. ${ }^{29}$

To check the abuse of any 'collective dominance' ${ }^{30}$ Commission usually examines particular situations for each case in the context of the

\footnotetext{
$28 \quad$ Wood pulp [1985] 85/202/EEC O.J L85/1.

29 Clearstream, COMP/38.096 (Decision on 2 June 2004).

$30 \quad$ Here as similar as 'market power.'
} 
express provisions of Article 82. The Commission condemns any exploitative practice as well as anti-competitive practices. EC competition law as well as the Commission tries to control the behavior of oligopolistics, separate or collective, while enjoying the collectively dominant position on a market. Good examples are the Microsoft and Coca cola cases.

\section{Microsoft}

This important case concerned the alleged abuse of a dominant position by Microsoft. Two problems were considered. First, it was alleged that Microsoft had used its dominance in the personal computer (PC) operating system market to leverage itself into a dominant position in the market for work group servers by not allowing competitors full access to the code required for efficient inter-operability with the windows system. Given the dominance of windows in the PC operating system market, rival work group server suppliers operated at competitive disadvantages to Microsoft because of this. Second, it was alleged that Microsoft had leveraged itself into the market for media players by bundling its Windows Media Player free with Windows. In this case, rival suppliers were put at a competitive disadvantage which enabled Microsoft to attain a high market share. In its decision on $24^{\text {th }}$ March 2004, the Commission concluded that Microsoft had abused its dominant position in both of these areas and is fined 497 million Euros. Microsoft appealed to the European Court but failed to alter the verdict given by the Commission. ${ }^{31}$

Microsoft, COMP/C-3/37.792 (Decision of 24 March 2004). For a detailed discussion on this case, see: Ahlborn, Christian and Evan, David S., "The Microsoft Judgment and its Implications for Competition Policy Towards Dominant Firms in Europe” (April 2008). Available at SSRN: http://ssrn.com/abstract=1115867. 


\section{Coca Cola}

The Coca Cola case ${ }^{32}$ involved a number of exclusivity conditions and rebate schemes operated by Coca Cola in the market for carbonated soft drinks. Amongst other things, it was found that Coca Cola used exclusive purchasing conditions in outlets it supplied and that it provided free chilled cabinets to outlets on condition that they only stock its products. In addition, it operated a system of rebates which had the effect of excluding other carbonated soft drink suppliers from the market. Following a five year investigation, the Commission found these practices were an abuse of a dominant position. In this context, however, it accepted commitments from Coca Cola aimed at increasing competition and consumer choice rather than imposing a fine. These commitments were:

- Coca Cola agreed not to impose exclusive purchasing conditions on its customers.

- It agreed not to pay retrospective rebates to customers who continued to buy the same amount or more of its products;

- $\quad$ It agreed not to require tie-ins of other products to the main products it supplied and not to offer rebates encouraging such ties; and

- $\quad$ Finally, it agreed to allow retailers to stock other soft drinks in its chiller cabinets to at least 20 percent of their capacity, if no other cabinets are available in an outlet.

Therefore, to determine the presence of collective dominance and the abuse of that market power, five essential elements ${ }^{33}$ must be established, these are: ${ }^{34}$

- $\quad$ more undertakings;

- $\quad$ a collective dominant position;

$32 \quad$ Joined Cases T-125 \& 127/97.

33 According to Article 82 of EC Treaty law.

$34 \quad$ Jones A and Sufrin B. Ibid. 


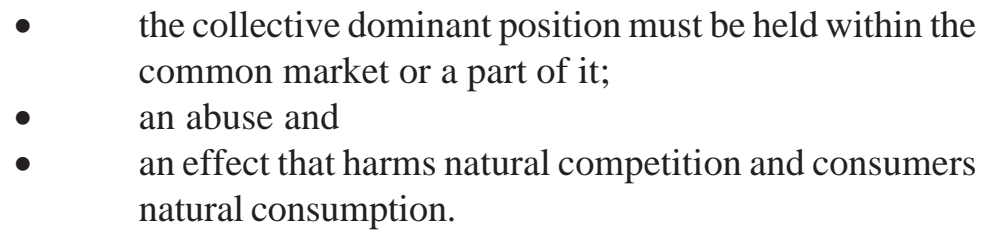

However, the Commission can impose a fine and even order a 'demerger' for the violation of Article 82 and for any collusive merger. According to Article 12(1) of Regulation No.17, the Commission can investigate into any matter in the market where there is chance of malpractice in any way. To uphold objectives of the EU competition policy, the Commission is not guided by very hard and fast rules. While blocking Airtours/First Choice merger activities Airtours offered remedial commitments, but they were rejected by the Commission. ${ }^{35}$

\section{RECENT INTERFACE BETWEEN EU COMPETITION POLICY AND THE NOTION OF 'COLLECTIVE DOMINANCE'}

The trends of using Article 82 and the EC Merger Regulation is that Article 82 mostly applies to control of abuses of an existing collective dominant position and the Merger Regulation is against the creation and strengthening of a collective dominant position. ${ }^{36}$ A separate trend is also being noticed in the development of an alternate effective method to deal with the abuse of a collective dominant position as it is proved unique and not fully suitable to run under Article 82 and the EC Merger Regulation as well.

The Commission uses broadly similar basic procedures and investigative tools for dealing ex post with infringements ${ }^{37}$ of Articles 81 and 82 and for decisions about notified mergers. A complaint or merger

$35 \quad$ Joelson M R. An International Antitrust Primer. (London: Kluwer Law International, 2001), 299.

$36 \quad$ Jones A and Sufrin B. ibid.

37 In the Community’s legal vocabulary, an “enforcement” matter is one that the Commission brings against a Member State for non-compliance with Treaty obligations or Community directives or other legislation. 
notification or a decision to start a procedure at the Commission's own initiative, is followed by an investigation by the Competition DirectorGeneral (DG Comp) and managed by a case handler. The evidence and proposed remedy are presented to the respondent in a "statement of objections." The respondent has a right of access to the investigative file and an opportunity to reply, in writing and at an oral hearing. The decision is taken by the Commission, on a recommendation of the Competition Commissioner. The Commission no longer processes applications for individual exemption or negative clearance, because it no longer has the power to issue them. The enforcement regulation provides for the possibility of a "guidance letter," but it sets conditions to discourage routine requests. The historically important system of notification and exemption has been eliminated. Now, the legal criteria describing what is prohibited and what qualifies for exemption apply directly. In effect, this approach puts a burden on companies to evaluate their agreements accurately, as they are at risk for making a mistake. ${ }^{38}$

The administrative process for applying the law is adapting in order to strengthen investigative powers and better incorporate economic evidence in decision-making, and thus convinces the courts while maintaining policy consistency in a system of decentralised enforcement. Member State competition agencies and courts can apply Community substantive law, and the informal "European Competition Network" (ECN) is the medium for facilitating inter-agency co-ordination. It is worth mentioning here that the modernisation of the enforcement process, by eliminating notification and prior approval of exemptions while sharing enforcement responsibility with national agencies, is designed, among other things, to redirect resources so that DG Comp can concentrate on complex, community-wide issues and investigations. A high priority here is to clarify the relationships among the leniency programs of the Community and the national enforcement agencies.

Again, coverage of Community competition law is broad and generally consistent, with no sectoral exclusions and few provisions for special enforcement processes. Treaty provisions that prohibit Member State measures contrary to Treaty rules about public undertakings and undertakings with special or exclusive rights have been the foundation

$38 \quad$ This is the system that has long been used to apply French competition law. France had advocated it for the original Regulation. 
for the long-term liberalisation program to reform traditional infrastructure monopolies. Treaty principles about controlling state aid try to prevent competition distorting actions by national public authorities. The Commission's new program for impact analysis of EU legislative proposals that might affect competition in the internal market is turning attention to avoiding unnecessary and disproportionate restrictions on competition in the legislation of the EU.

However, Commission decisions are subject to oversight by the two European Courts. The ECJ, ensures enforcement against Member States, decides disputes between the Community and Member States (and between Community Institutions) and ensures uniform interpretation of Community law by deciding questions referred to it by national courts. The Court of First Instance (CFI) was created to reduce the ECJ workload and backlog by dealing with the cases with no political or constitutional importance and those involving complex facts. The ECJ can review CFI judgments, but only on matters of law. The possibility of a substantive appeal to the courts brings the Community's competition enforcement system into compliance with the European Convention on Human Rights. The ECJ held in 1980 that the Commission process did not provide the "independent and impartial tribunal" that the Convention requires. The decision of the Commission in an infringement matter, to terminate the violation or pay a fine, is binding. The parties can bring an action in the CFI to annul it, on grounds of fact or law. Filing the court action does not itself suspend the application of the decision. The parties can request that the CFI suspend the application pending the appeal. For fines, the Commission's practice is to agree to suspend pending appeal, on condition of providing a bank guarantee for the fine plus interest.

If the courts annul a merger decision, that action does not amount to clearance; rather, the matter is sent back to the Commission to reexamine the notification, potentially repeating the two-phase merger review process. The judicial process has normally taken 2-3 years to complete. The CFI adopted an expedited process, providing for written procedures and a full hearing, through which it can complete a matter within 8-10 months after a Commission decision. Thus there is now a realistic prospect of judicial oversight of time-sensitive matters such as mergers.

Nevertheless, rules about standing are generous, so complainants are regarded as individually concerned and hence can challenge the Commission's action or inaction. The scope of review under the general 
Treaty provision looks limited and supervisory, not involving reexamination on the merits (Article 230). The grounds for judicial review are lack of competence, infringement of an essential procedural requirement, the Treaty itself or a rule of law related to its application and misuse of power. Despite this apparently narrow scope, the CFI and the ECJ have also overturned Commission decisions for inadequacy of evidence or error of fact. The courts have devised a category of "comprehensive review," and when applying it the CFI will control the accuracy and quality of the Commission's reasoning about economic and market analysis. The court rules provide for commissioning independent expert reports. However, the ECJ relied on reports of its appointed experts to overturn the Commission's findings and conclusions. ${ }^{39}$ The CFI at first rejected about half of the Commission's decisions imposing substantial fines; however, those actions may have represented an effort to set ground rules about procedures, since several of the rejected fines were later upheld after the Commission revisited the matters to correct the procedural flaws. ${ }^{40}$

But, if a separate court took on more responsibility for making records and deciding cases, it would likely play a larger role in determining policy too. As Community competition policy moves beyond law-driven market integration toward a more economic approach, courts may need to articulate a more coherent conception of competition and policy goals. ${ }^{41}$ Perhaps a specialist competition court could fill that role. Changes to the CFI's status due to the Treaty of Nice, prepared the way by giving the CFI its own basis for jurisdiction and authorising it to annex panels to hear matters in the first instance, with an appeal to the CFI. Though this was conceived as an outlet for staff cases, it might foreshadow the creation of a separate competition court as a first-instance decision-maker. ${ }^{42}$ But

\footnotetext{
$39 \quad$ Wood pulp [1985] 85/202/EEC O.J L85/1.

$40 \quad$ Wils and Wouter P.J., "The Combination of the Investigative and Prosecutorial Function and the Adjudicative Function in EC Antitrust Enforcement: A Legal and Economic Analysis,” World Competition Law \& Economics Review, 27-2 (2004), 201-224.

41 Gerber David. Law and Competition in Twentieth Century Europe: Protecting Prometheus (Oxford: Oxford University Press, 1998), 107.

42 The regulations to enforce and impose fines for violations of Articles 81 and 82 are authorised under Article 83. Court jurisdiction under Article 229 is based on reviewing penalties. The legal basis for the merger regulation, though, is Article 308, and the merger control system is not based on imposing penalties.
} 
creation of a new "cartel court" at this time would be premature. It would undermine the role of the Commission and the Council in setting policy directions, and it would encourage DG Comp to act more like a prosecutor than a decision-maker. Short of changing the courts' basic function in the process, they might be given more comprehensive powers to consider Commission decisions on the basis of appeals rather than judicial review. The European courts now review Commission decisions for legal and procedural deficiencies, exercising full control only over the sanctions imposed. If the court rejects the Commission's finding of infringement, it can only annul the decision and send it back to the Commission for further proceedings. An alternative would be to authorise a full appeal, leading to entry of final judgment by the court.

\section{CONCLUSION}

The notion of 'collective dominance' plays a central role in the development of the EU competition policy and its related institutions. Gradually this notion has distinctively been based on the direct application of law to economic actors rather than on administrative exercise of policy discretion or on political or interest-group bargaining. This development would be further extended if the EC could provide detailed guideline on this notion in which the economic background of the concept of collective dominance is explicitly explained. 